\title{
A PARAMETER-BASED METHOD FOR TRANSLATING POLISH CONTRACT LAW TERMS INTO SPANISH
}

\begin{abstract}
The paper deals with problems of legal translation from Polish into Spanish. It analyses selected terms related to contracts which are regulated in the Polish Civil Code and their possible translations into Spanish. In order to find adequate translation equivalents the author applies the method of parametrisation of legal terms (along with the method of comparing parallel texts and the skopos theory). The parametrisation of legal terms helps to systematically characterise and compare them and thus to identify differences in the meanings of the source language and target language terms and to choose the best equivalents. It may also facilitate the selection of a technique of providing translation equivalents for non-equivalent or partially equivalent terms. Parametrisation is understood as determining for each analysed term a set of properties it shows with respect to translationally relevant parameters - one property out of each parameter. A parameter is conceived of as a set of homogeneous properties.

Keywords: legal translation, Polish-Spanish translation, parametrisation, legal terminology.
\end{abstract}

\section{Introduction}

One of the major challenges a person translating legal texts is faced with is to find, in the target language, adequate equivalents of legal terms used in the source language. To this aim, various techniques of providing equivalents for non-equivalent or partially equivalent terms can be applied (cf. e.g. Newmark 1988; Kierzkowska 2002). In this paper, a parameter-based method for analyzing legal terms and choosing adequate translation equivalents for them will be presented (cf. Bańczerowski \& Matulewska 2012; Matulewska 2013) and applied to the Polish-Spanish language pair ${ }^{1}$. To illustrate how this method works, selected terms pertaining to the area of law of obligations, more specifically, names of contractual obligations used 
in the Polish Civil Code will be analysed within its framework and their possible Spanish equivalents will be considered. Other research methods applied subsidiarily in this study are:

- comparison of parallel texts ${ }^{2}$,

- the skopos theory (see e.g. Vermeer 2001),

- the pragmatic model for the translation of legal terms (Kierzkowska 2002: 72-123).

As proposed within Vermeer's skopos theory, translators should take into consideration the purpose of the translation and the character of its recipients. Depending on these factors, translators may make different decisions. A decision made for a text aimed at a more general audience, or in other words a distant recipient, in accordance with the pragmatic model for translating legal terms developed by Kierzkowska (2002: 88-89), i.e. a recipient who is not a specialist, is not versed in the culture of the source text and has no motivation to know it better, does not need to take all legal niceties into consideration. By contrast, if the translation is to be made for a close recipient, i.e. a recipient who is versed in the culture of the source text, who is a specialist, e.g. a lawyer or a business person operating in a given country for whom all legal details matter, translators should consider which aspects (manifesting themselves in their properties to be discussed below) of the term are most relevant for their purpose and this should determine the final choice of an equivalent. The parametrisation of legal terms is intended to be an instrument serving to precisely characterise both source and target language terms, to compare them systematically with respect to their properties and finally to choose an adequate term in the target language.

The corpus of the parallel texts analysed for the purpose of this study includes: the Polish Civil Code, the Spanish Civil Code, and the Galician Civil Code. In addition, selected dictionaries have been consulted.

\section{Method of parametrisation}

The units of parametrisation, which will be presented in what follows, are terms, whether belonging to the source language or the target language. Every such term shows a number of properties that are translationally relevant. For instance, the Polish term uzyczenie 'commodate' is characterised by such properties as: 'civil law' (branch of law it pertains to), 'law of contracts' (sub-branch of law it pertains to), 'legislation' (text genre it is used in), and others. In order to provide a systematic description of legal terms, homogeneous properties, i.e. properties of the same kind and compa- 
rable with one another, are grouped into sets; for example, 'civil law', 'penal law', both being names of branches of law, are grouped together into one set. These sets are called parameters. Thus, a parameter is a set of homogeneous properties. The list of parameters also includes one reflecting the meaning of a term ${ }^{3}$.

The proposed parameters should be adequate to both languages in order to make a systematic comparison between Polish and Spanish terms possible. Sometimes, however, it may be impossible to assign a property out of a given parameter to a term. Therefore, every parameter also contains a property called 'indeterminacy', which will be assigned to a term if it is not describable by any other property with respect to this particular parameter. Particularly, this concerns the parameter 'Text language variety', which is not applicable for Polish as having only one legal language variety. Consequently, Polish terms always show the property 'indeterminacy' with respect to this parameter. This parameter is, by contrast, relevant for Spanish, which is an official language in more than 20 countries where legal terminology can differ.

In what follows, a set of translationally relevant parameters is presented for the purpose of finding Spanish equivalents for Polish names of contracts ${ }^{4}$. Next, parametrisation of the terms to be translated is carried out, which means that for every term a set of properties that it shows with respect to the parameters - one property out of each parameter - is determined. The set of properties that are shown by a term with respect to all parameters is referred to as its parametric characterisation.

The method presented here makes it possible to compare terms interand intralingually in terms of properties they show with respect to particular parameters. If two terms show the same property with respect to a parameter, they are convergent with respect to it. By contrast, if they show different properties with respect to a parameter, they are said to be complementary (Matulewska 2013). The application of the method of parametrisation to Polish-Spanish legal translation will be exemplified by means of three Polish legal terms: użyczenie, dożywocie and dzierżawa.

\section{Case 1: Ǘyczenie}

The first step is to characterise the source language term by determining the properties it shows with respect to the parameters. The next step is to determine the closest target language equivalent. To this aim, a comparison of parallel texts is carried out. As a result, the Spanish term comodato is 
identified in the Spanish Civil Code as a possible translation equivalent of the Polish term uzyczenie. The parametrisation of this term allows us to determine precisely how close it is to the Polish one. Its parametric characterisation is presented in Table 1 along with that of the Polish term.

Table 1

\section{Parametric characterisation of the Polish term użyczenie and Spanish term comodato}

\begin{tabular}{|c|c|c|}
\hline \multirow{3}{*}{ Parameter } & \multicolumn{2}{|c|}{ Terms } \\
\hline & Polish (source language) & Spanish (target language) \\
\hline & użyczenie & comodato \\
\hline The author of the text & legislator & legislator \\
\hline Source-text delivery form & written & written \\
\hline Source-text status & binding & binding \\
\hline Branch of law & civil law & civil law \\
\hline Sub-branch of law & law of contracts & law of contracts \\
\hline Text genre & legislation & legislation \\
\hline Text sub-genre & code (national Polish Civil Code) & code (national Spanish Civil Code) \\
\hline The language of the text & Polish & Spanish \\
\hline Text language variety & indeterminacy & Peninsular Spanish \\
\hline Lect & language for specific purposes & language for specific purposes \\
\hline Sub-lect & language of law & language of law \\
\hline Meaning of the term & $\begin{array}{l}\text { one person (the lender) delivers to } \\
\text { the other (the borrower) a thing so } \\
\text { that he or she can use it for a certain } \\
\text { time and return it (cf. art. } 710 \text { of the } \\
\text { Polish Civil Code) }\end{array}$ & $\begin{array}{l}\text { one person (the lender) delivers to } \\
\text { the other (the borrower) a thing so } \\
\text { that he or she can use it for a certain } \\
\text { time and return it (cf. art. } 1740 \text { of } \\
\text { the Spanish Civil Code) }\end{array}$ \\
\hline $\begin{array}{l}\text { Required form of the } \\
\text { contract }\end{array}$ & notarised not required & notarised not required \\
\hline
\end{tabular}

A comparison of the two terms with respect to the parameters makes it possible to conclude that the term comodato is a translation equivalent which is sufficiently close to the Polish term. Both terms show the same properties - in other words, are convergent - with respect to nearly all parameters (except for obvious differences such as the language of the text). To sum up, it is a rare instance of a practically full equivalence of two terms.

\section{Case 2: Umowa o dożywocie}

The translation of the Polish term umowa o dożywocie is a more problematic case. As for possible Spanish equivalents, Polish-Spanish dictionaries suggest mantenimiento vitalicio (Perlin 2002: I, 229) and vitalicio (Komarnicki et al. 2010: 195). However, mantenimiento vitalicio is not used in 
Spanish legal texts and therefore cannot be characterised with respect to the parameters proposed. It should not be considered as a potential translation equivalent for the Polish term. The comparison of parallel texts results in the identification of two other terms that may be taken into consideration. One is contrato de vitalicio, a term used in the Civil Code of Galicia (one of Spain's autonomous communities). It is also indicated in the dictionary by Komarnicki et al. (as vitalicio). The other term is contrato de alimentos, which is used in the Spanish Civil Code. The parametric characterisations of these terms are presented in Table 2.

It can be observed that the Polish term umowa o dożywocie and the Spanish term contrato de vitalicio differ from each other with respect to parameters 'Text sub-genre' and 'Meaning of the term'. Both are used in legal language and in a statutory instrument, however, while the Polish term occurs in a national civil code, the Spanish one occurs in a local one. The crucial difference lies in their meaning: under the Polish dożywocie contract, the object of contract is the transfer of ownership of an immovable property in exchange for a lifetime maintenance; by contrast, under the Spanish contrato de vitalicio, the ownership transfer is not restricted to immovable properties as it is also allowed to transfer ownership of other things or rights. In addition, the duties of the purchaser under contrato de vitalicio which are enumerated in the art. 148 of the Galician Civil Code and consist in providing the other part with maintenance, lodging, clothing, medical care as well as help and care (also emotional care) do not include taking them in as a household member, which is the case under the Polish umowa o dożywocie. In addition, the regulations concerning contrato de vitalicio do not mention the purchaser's duty to give the other party a funeral appropriate to the local traditions, which again is the case under umowa o dożywocie.

As for the second potential Spanish equivalent, namely contrato de alimentos, it is convergent with the Polish term umowa o dożywocie with respect to nine parameters. Importantly, it differs from the Polish term quite significantly with respect to parameters 'Meaning of the term' and 'Required form of the contract'. As far as meaning is concerned, the meaning of contrato de alimentos is, to a great extent, close to the meaning of the Spanish contrato de vitalicio (the transfer of ownership may concern things of any kind or rights; there is no obligation to take the other party in as a household member and no obligation to give them a specific funeral). The discrepancy concerning the required form of the contract consists in that the form for the Spanish contrato de alimentos is not specified, while the Polish umowa o dożywocie requires a notarised document ${ }^{5}$. 
Table 2

\section{Parametric characterisations of the Polish term umowa o dożywocie and the Spanish terms contrato de vitalicio and contrato de alimentos}

\begin{tabular}{|c|c|c|c|}
\hline \multirow{3}{*}{ Parameter } & \multicolumn{3}{|c|}{ Terms } \\
\hline & $\begin{array}{c}\text { Polish term } \\
\text { (source language) }\end{array}$ & $\begin{array}{c}\text { Spanish term } 1 \\
\text { (target language) }\end{array}$ & $\begin{array}{c}\text { Spanish term } 2 \\
\text { (target language) }\end{array}$ \\
\hline & umowa o dożywocie & contrato de vitalicio & contrato de alimentos \\
\hline The author of the text & legislator & legislator & legislator \\
\hline Text delivery form & written & written & written \\
\hline Text status & binding & binding & binding \\
\hline Branch of law & civil law & civil law & civil law \\
\hline Sub-branch of law & law of contracts & law of contracts & law of contracts \\
\hline Text genre & legislation & legislation & legislation \\
\hline Text sub-genre & $\begin{array}{l}\text { code (national Polish } \\
\text { Civil Code) }\end{array}$ & $\begin{array}{l}\text { code (local - Galician } \\
\text { Civil Code) }\end{array}$ & $\begin{array}{l}\text { code (national Spanish } \\
\text { Civil Code) }\end{array}$ \\
\hline $\begin{array}{l}\text { The language of the } \\
\text { text }\end{array}$ & Polish & Spanish & Spanish \\
\hline Text language variety & indeterminacy & Peninsular Spanish & Peninsular Spanish \\
\hline Lect & $\begin{array}{l}\text { language for specific } \\
\text { purposes }\end{array}$ & $\begin{array}{l}\text { language for specific } \\
\text { purposes }\end{array}$ & $\begin{array}{l}\text { language for specific } \\
\text { purposes }\end{array}$ \\
\hline Sub-lect & language of law & language of law & language of law \\
\hline Meaning of the term & $\begin{array}{l}\text { the owner of an immov- } \\
\text { able property transfers } \\
\text { the property thereof } \\
\text { to a person (assignee), } \\
\text { who undertakes to pro- } \\
\text { vide the former with } \\
\text { subsistence for the } \\
\text { rest of his or her life, } \\
\text { which means that, un- } \\
\text { less agreed otherwise, } \\
\text { he must take him in as } \\
\text { a household member, } \\
\text { provide him with food, } \\
\text { clothing, home, electric- } \\
\text { ity and heating, provide } \\
\text { him with assistance and } \\
\text { care in the case of ill- } \\
\text { nesses and give him, at } \\
\text { his own expense, a fu- } \\
\text { neral appropriate to the } \\
\text { local traditions (cf. art. } \\
908 \text {. } 1 \text { of the Polish } \\
\text { Civil Code) }\end{array}$ & $\begin{array}{l}\text { one or more person un- } \\
\text { dertake with respect } \\
\text { to another person or } \\
\text { persons to supply sub- } \\
\text { sistence, according to } \\
\text { conditions they agree, } \\
\text { in exchange for the } \\
\text { transfer of property of } \\
\text { certain things or rights } \\
\text { (cf. art. } 147 \text { of Galician } \\
\text { Civil Code) }\end{array}$ & $\begin{array}{l}\text { one of the parties un- } \\
\text { dertakes to provide } \\
\text { a person with acco- } \\
\text { modation, subsistence } \\
\text { and assistance of all } \\
\text { kind for all his life in } \\
\text { exchange for the trans- } \\
\text { fer of capital consisting } \\
\text { in any class of things or } \\
\text { rights (cf. art.1791 of } \\
\text { the Spanish Civil Code) }\end{array}$ \\
\hline $\begin{array}{l}\text { Required form of } \\
\text { the contract }\end{array}$ & notarised & notarised & notarised not required \\
\hline
\end{tabular}

To sum up, both contrato de vitalicio and contrato de alimentos differ from umowa o dożywocie as regards the parameter 'Meaning of the term'. Contrato de vitalicio is closer to umowa o dożywocie than contrato de alimentos as far as the requirement of notarised form is concerned. However, 
it is not used in the same kind of source text (local statutory instrument) and, arguably, it is better to translate a term occurring in a national legal act by means of a term taken from a national legal act, too. As we can see, neither of the two potential Spanish equivalents for umowa o dozywocie is a full equivalent. Therefore, it is necessary to consider some further points. If the translation is to be made for a distant recipient, both contrato de vitalicio and contrato de alimentos could be used, however, the latter seems preferable because it occurs in a national legal text. If, by contrast, a close recipient is being addressed, none of the ready-made terms occurring in Spanish legal texts seem adequate enough in the case of umowa o dożywocie. As a solution, the translator may consider using a descriptive equivalent in which all the relevant differences would be explained. In the case of umowa $o$ dożywocie, however, such an equivalent might be too long. The differences between the two concepts can also be explained in a footnote. Another option is to add a modifier, e.g. polaco 'Polish', to create the phrase contrato de alimentos polaco, which would suggest that there are more or less significant differences between the Polish and Spanish contracts of this type.

\section{Case 3: Dzierżawa}

Another term the translation of which will be discussed in the light of the method proposed is the Polish term dzierżawa. The analysis of the Polish and Spanish Civil Codes results in the identification of the term arrendamiento (art. 1543 of the Spanish Civil Code) as a possible translation equivalent. The properties shown by the Polish and Spanish terms with respect to the parameters are given in Table 3 .

It can be observed that the two terms are convergent with respect to most parameters except the parameter 'Meaning of the term'. The main difference between Polish dzierżawa and Spanish arrendamiento consists in that while the former gives the right to use and to acquire fruits (conjunction), the latter, according to the tenor of the relevant passage of the text, which reads el goce o uso, gives the right to acquire fruits (goce) or to use (uso). Albaladejo remarks that this legal definition is not clear as it may entail misunderstandings (2011a: 251). Therefore, he prefers to say that arrendamiento gives either the right to use (el uso) or to use and acquire fruits (uso y el goce). Thus, according to this approach, the Spanish conjunction $o$ is understood as conveying the meaning of inclusive disjuncton ${ }^{6}$. Albaladejo says, consequently, that there exist two types of arrendamiento: arrendamiento de uso and arrendamiento de uso y disfrute (disfrute 
Table 3

\section{Parametric characterisations of the Polish term dzierżawa and the Spanish term arrendamiento}

\begin{tabular}{|l|l|l|}
\hline \multirow{2}{*}{} & \multicolumn{2}{|c|}{ Terms } \\
\cline { 2 - 3 } & \multicolumn{1}{|c|}{ Polish term (target language) } & \multicolumn{1}{c|}{ Spanish term (target language) } \\
\cline { 2 - 3 } $\begin{array}{l}\text { The author of the source } \\
\text { text }\end{array}$ & legislator & \multicolumn{1}{c|}{ arrendamiento } \\
\hline Source-text delivery form & written & legislator \\
\hline Source-text status & binding & binding \\
\hline Branch of law & civil law & civil law \\
\hline Sub-branch of law & law of contracts & law of contracts \\
\hline Text genre & legislation & legislation \\
\hline Sub-genre & code (national Polish Civil Code) & code (national Spanish Civil Code) \\
\hline The language of the text & Polish & Spanish \\
\hline $\begin{array}{l}\text { Source-text language } \\
\text { variety }\end{array}$ & indeterminacy & Peninsular Spanish \\
\hline Lect & language for specific purposes & language for specific purposes \\
\hline Sub-lect & language of law & language of law \\
\hline Meaning of the term & $\begin{array}{l}\text { one party undertakes to give to the } \\
\text { other a thing for use and acquisition } \\
\text { of fruits for a limited or unlimited } \\
\text { period of time and the other party } \\
\text { undertakes to pay an agreed rent (cf. } \\
\text { art. } 693 \text { § 1. of the Polish Civil Code) }\end{array}$ & $\begin{array}{l}\text { one party undertakes to give to the } \\
\text { tion of fruits for a limited period of } \\
\text { 154 of the Spanish Civil Code) }\end{array}$ \\
\hline $\begin{array}{l}\text { Required form of the } \\
\text { contract }\end{array}$ & notarised not required & notarised not required \\
\hline
\end{tabular}

'the right to acquire fruits' is synonymous with goce). If we follow Albaladejo's explanation, then the Spanish term arrendamiento is too broad as it also refers to what in the Polish legal language is denoted by means of the term najem. Within the contract of najem, the party is only entitled to use a thing, without acquiring its fruits. Therefore, when translating the Polish term dzierżawa, Spanish arrendamiento must be specified so as to make it clear that the acquisition of fruits is included in its meaning. Thus, dzierżawa may be translated into Spanish as arrendamiento de uso y disfrute (while najem may be translated as arrendamiento de uso). Albaladejo (2001a: 251; 2001b: 628) observes that these two concepts are present in the Spanish civil law but, in contrast to legal systems of some other countries, they are not treated separately there.

Another possible term that might seem to be a potential equivalent for Polish dzierżawa (and najem) is alquiler. Its dictionary definition is: 'Uso, durante cierto tiempo, de algo que es propiedad ajena, a cambio de pago de una cantidad de dinero fijada de antemano' ['The use, for a certain time, 
of a thing that is someone else's property, in exchange for a sum of money agreed in advance'] (Maldonado González 2000: 84). This term, however, is not a legal term and should not be considered as a potential translation equivalent if other, more suitable terms can be used.

\section{Conclusions}

As it has been shown above, the method of parametrisation of legal terms (along with the method of comparing parallel texts and the skopos theory) can be very useful in the process of translation of legal terms. The first necessary step to take is to find potential equivalents in the target language. The method of comparing parallel texts seems to be the best option, especially in the case of Polish-Spanish translation, as there are few reliable sources (e.g. dictionaries) that can be consulted. In order to choose the best translation equivalents for legal terms, it is necessary to characterise the source language and target language terms in a systematic way, compare them intra- and interlingually and thus to identify differences in their meanings. The method of parametrisation can be used to achieve this goal. Finally, when deciding which equivalent is the most suitable, translators should take into consideration the purpose of the translation and the character of its recipients and, if necessary, consider applying one of the techniques of providing equivalents for non-equivalent or partially equivalent terms.

\section{N O T E S}

1 The research has been financed from the research grant no. DEC-2012/07/E/HS2/ 00678, titled Parametrisation of legilinguistic translatology in the scope of civil law and civil procedure awarded by the National Science Centre of the Republic of Poland (Sonata Bis Program).

2 A parallel text can be defined as follows: "A text that treats the same or a closely related topic in the same subject field and that serves as a source for the 〈mots justes $\rangle$ and $\langle$ terms $\rangle$ that should ideally be incorporated into the $\langle$ target text $\rangle$ to ensure collocational 〈cohesion〉" (Delisle et al. 1999: 166) or according to the French version of the definition: "〈Texte〉 en 〈langue d'arrivée〉 qui appartient au même genre que le 〈texte de départ〉 ou

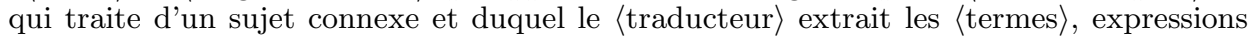
ou connaissances thématiques dont il a besoin pour effectuer sa〈traduction〉" (Delisle et al. 1999: 81).

3 Since the meaning of a legal term is a complex entity, only the crucial features of its content that make it possible to differentiate it from other terms will be taken into consideration here. 
4 The general framework of this method, illustrated here with examples for the PolishSpanish language pair, has been developed within the project indicated in footnote 1 (involving Polish and six other languages).

${ }^{5}$ It is interesting to note that to a non-specialist the term contrato de alimentos might seem to refer only to nourishment, i.e. food and drink, because this is how alimento is defined in the authoritative Spanish dictionaries (e.g. Maldonado González 2000: 78). However, in Spanish legal language (used in both Galician and Spanish Civil Law) the term alimentos is understood in a special sense, as including nourishment, accomodation, clothing, medical assistance etc.

${ }^{6}$ Albaladejo observes that if the contracting parties do not stipulate which of the two types of arrendamiento is meant in the contract, one should follow the common understanding according to which the type normally depends on whether the object produces fruits or not (2011b: 628).

\section{R E F E R E N C E S}

Albaladejo, M. (2011a). Compendio de derecho civil. Madrid: Edisofer, S.L.

Albaladejo, M. (2011b). Derecho civil. Part II: Derecho de obligaciones. Madrid: Edisofer, S.L.

Bańczerowski, J. \& Matulewska, A. (2012). Towards the Foundations of Legilinguistic Translatology. In P. Grzegorczyk, K. Knoppek \& M. Walasik (Eds.), Proces cywilny. Nauka-Kodyfikacja-Praktyka. Ksiega jubileuszowa dedykowana Profesorowi Feliksowi Zedlerowi (pp. 1225-1261). Warszawa: Wolters Kluwer Polska.

Delisle J., Lee-Jahnke, H. \& Cormier, M.C. (Eds.) (1999). Translation Terminology. Amsterdam/Philadephia: John Benjamins Publishing Company.

Kierzkowska, D. (2002). Ttumaczenie prawnicze [Legal translation]. Warszawa: Wydawnictwo TEPIS.

Komarnicki, M., Komarnicki, I. \& Komarnicka, E. (2010). Słownik terminologii prawniczej hiszpańsko-polski, polsko-hiszpański [A Dictionary of Legal Terms: Spanish-Polish, Polish-Spanish]. Warszawa: Wydawnictwo C.H. Beck.

Maldonado González, C. (Ed.). (2000). Clave. Diccionario de uso del español actual. Madrid: Ediciones SM.

Matulewska, A. (2013). Legilinguistic Translatology. A Parametric Approach to Legal Translation. Frankfurt am Main: Peter Lang Publishing House.

Newmark, P. (1988). A Textbook of Translation. New York: Prentice-Hall International.

Perlin, O. 2006. Wielki słownik polsko-hiszpański z suplementem [Great PolishSpanish Dictionary with a Supplement], vol. I-II. Warszawa: Wiedza i Ty/Wiedza Powszechna.

Vermeer, H.J. (2001). Skopos and Commission in Translational Action. In L. Venuti \& M. Baker (Eds.), The Translation Studies Reader (pp. 221-232). London, New York: Routledge. 
A Parameter-based Method for Translating Polish Contract Law Terms...

\section{Source texts}

Galician Civil Code - Ley 2/2006, de 14 de junio, de derecho civil de Galicia. Texto consolidado. Última modificación: 23 de julio de 2012.

Polish Civil Code - Kodeks cywilny. Ustawa z 23 kwietnia 1964 roku (Dz. U. Nr 16, poz. 93 ze zmianami).

Spanish Civil Code - Real Decreto de 24 de julio de 1889 por el que se publica el Código Civil. Texto consolidado. Última modificación: 29 de julio de 2015. 